\title{
Undergraduate nurses' experience of the family health assessment as a learning opportunity
}

Authors:
Juliana J. Willemse ${ }^{1}$
Elma W. Kortenbout ${ }^{1}$
Affilliations:
'School of Nursing, University
of the Western Cape,
South Africa
Correspondence to:
Juliana Willemse
Email:
jjwillemse@uwc.ac.za
Postal Address:
Private Bag X17, Bellville
7535, Cape Town,
South Africa
Dates:
Received: 01 Oct. 2010
Accepted: 02 May 2012
Published: 24 July 2012
How to cite this article:
Willemse, J.J. \& Kortenbout,
E.W., 2012, 'Undergraduate
nurses' experience of the
family health assessment as a
learning opportunity', Health
SA Gesondheid $17(1)$, Art.
\#582, 9 pages. http://dx.doi.
org/10.4102/hsag.v17i1.582

(C) 2012. The Authors. Licensee: AOSIS OpenJournals. This work is licensed under the Creative Commons Attribution License.
The practice of community health nursing $(\mathrm{CHN})$ may enhance the life experiences of families and communities, particularly amongst the poor and socially marginalised. CHN provides for a deeper understanding of the health status of families living within communities, for example, where and how they live, their cultural context and their ability to identify resources available to assist with their health care (Allender, Rector \& Warner 2010:17).

This qualitative phenomenological study reflects on the self-reported lived experiences of undergraduate CHN students at the University of the Western Cape in the City of Cape Town, South Africa. These students conducted a family health assessment (FHA) learning task at the homes of families within communities.

Purposive and convenience sampling was used by students who had conducted an FHA. Fourteen students agreed to participate in the study, of whom nine were interviewed, two withdrew and the remaining three were not interviewed since no new data were emerging during interviews, indicating that saturation had been reached.

During in-depth interviews with seven female and two male students, data for the exploration of the lived experiences was gathered through the following question: 'How did you experience the FHA?' Field notes were taken and used to capture non-verbal communication of participants. The focus of the study was to explore the lived experiences of students and not those of the family on whom the FHA was completed.

Data collected were categorised into themes, guided by the systematic data analysis process of Tesch (1990) cited in Cresswell (2003:192). Four themes emerged: challenges of family selection, challenges of safety, socio-cultural challenges and academic challenges experienced by the participants. This study will inform future research and curriculum planning for $\mathrm{CHN}$ education in a multifaceted context.

Die praktyk van gemeenskapsgesondheidverpleging (GGV) het die potentiaal om die lewenservaringe van families en gemeenskappe te verryk, veral in arm en voorheen benadeelde gemeenskappe. GGV verskaf 'n dieper begrip met betrekking tot die welstand van families in hulle gemeenskappe, byvoorbeeld, waar en hoe hulle leef, hul kultuur en hulle vermoë om beskikbare hulpbronne te identifiseer om sodoende hulle gesondheid te bevorder (Allender, Rector \& Warner 2010:17).

Hierdie kwalitatiewe fenomonologiese studie is 'n refleksie op die self-gerapporteerde persoonlike ervaringe van voorgraadse gemeenskapsgesondheidverpleging studente (VGVS) verbonde aan die Universiteit van Wes Kaapland, in Kaapstad, Suid-Afrika. Hierdie studente het as 'n werksopdrag 'n familie gesondheidsberaming (FGB) by wonings van gesinne in die gemeenskap voltooi.

'n Gerieflikheids- en doelgerigte steekproefneming is gedoen met studente wat die FGB voltooi het. Veertien studente het ingestem om aan die studie deel te neem, waarvan daar onderhoude met nege gevoer is. Twee studente het onttrek en die oorblywende drie is nie genader nie weens die feit dat daar geen nuwe data na vore gekom het nie, wat daarop dui dat saturasie bereik was.

Data vir die verkenning van persoonlike ervaringe is deur in-diepte onderhoude met sewe vroulike en twee manlike studente ingesamel deur die volgende vraag te vra: 'Wat was jou ervaring met die voltooing van die FGB?' Veldnotas was geneem om nie-verbale kommunikasie van die studente aan te teken. Die fokus van die studie was gerig om die persoonlike ervarings van die VGVS te verken met verwysing na die FGB wat hulle voltooi het. Die fokus was nie gerig op die ondervindinge van die familie op wie die FGB gedoen is nie.

Die ingesamelde data is in temas gekategoriseer volgens die sistematiese data analitiese proses van Tesch (1990), soos omskryf in Cresswell (2003:192). Vier temas is geïdentifiseer naamlik: uitdagings ten opsigte van die keuring van ' $n$ geskikte familie: uitdagings ten opsigte van veiligheid, sosiokulturele uitdagings en akademiese uitdagings soos ervaar is deur die deelnemende studente. Die belangrikheid van die studie is om toekomstige navorsing en kurrikulumbeplanning in gemeenskapsgesondheidverpleging binne ' $n$ diverse konteks te bevorder. 


\section{Introduction \\ Problem statement}

The family health assessment (FHA) has gained recognition as an assessment strategy in community health nursing $(\mathrm{CHN})$, providing a comprehensive picture of the health status of each member of a family (Hattingh, Dreyer \& Roos 2006:144; Maurer \& Smith 2009:347). The FHA provides insight into the familial demographics; family structure and roles; problem-solving patterns; functioning; values and beliefs; communication, decision-making and coping patterns; health behaviour; social and cultural patterns; and physical, psychological and spiritual environment of the family. This basic information informs the $\mathrm{CHN}$ practitioner on the health status of the family and guides the design of an appropriate nursing intervention where necessary (Allender, Rector \& Warner 2010:510-511).

In keeping with the Millennium Development Goals, a community health nurse can implement various interventions to promote the health of a family. She or he can assume the role of a partner in assisting a family to assess, improve and evaluate their current health status and health practices. The FHA is used in the preparation of community health nurses as a learning strategy to enable them to obtain information about the family regarding physical and social health status, relationships within the family, environment, type of housing, hygiene and the neighbourhood in which the family lives (Hattingh, Dreyer \& Roos 2006:144). To manage the health of a family effectively and holistically it is important that the community health nurse goes into the home and environment of the family to assess health needs and devise health promotion strategies (Harmon Hanson, Gedaly-Duff \& Rowe Kaakinen 2005:7-11).

The purpose of this study was to explore the lived experiences of undergraduate $\mathrm{CHN}$ students during their clinical fieldwork whilst conducting an FHA in a community. The study was conducted within the communities of the greater Cape Town area.

Primary health care includes the following: (1) education about health problems and methods to control and prevent these problems,(2) promotion of proper nutrition (3) provision of water and basic sanitation, (4) care of highrisk groups such as mothers and children, (5) immunisation against infectious diseases, (6) prevention and control of epidemics, and (7) available treatment and drugs for the common illnesses and injuries (Naudé \& Setswe 2000:2).

Whilst conducting an FHA, the health professional may be able to identify the essential and overall basic care that a person, family or community may need to remain healthy, through the provision of affordable and accessible health care (Naudé \& Setswe 2000:2).

Community health undergraduate nursing students within the South African context gain valuable experience through clinical placements at the primary level of care in community health clinics. Adequate experience in the clinical setting provides students with the opportunity to develop confidence and competence in relevant clinical skills (Croxon \& Maginnis 2009:236).

As part of the fulfilment of the curriculum requirements for $\mathrm{CHN}$ within the Bachelors Degree Nursing Programme at the University of the Western Cape (UWC), third-year undergraduate students are placed at community health clinics that have been accredited as training or educational facilities (South Africa, Nursing Act: Act No. 33 2005; South African Nursing Council 1985). During this time they conduct an FHA within family homes.

Students were prepared for the learning task of conducting an FHA by being provided with structured guidelines that were discussed in class. In carrying out an FHA the following must be completed:

Biographical data: A detailed genogram of the selected family including all significant family members, even if not residing in the same home, for example, grandparents, aunts and uncles.

Environmental data: Assessment of the physical environment such as type of housing, house size, hygienic practices, availability of essential services (e.g. electricity, clean running water), community resources and health hazards. Students need to name and describe factors that could be a threat to the families' health.

Social data: An assessment of family relationships, social network, social activities and support systems.

Psychological data: Identification of psychological stressors and the coping mechanisms of the family.

Economic data: The source of income of the family and whether they are able to make ends meet on their income.

The students were informed that they were allowed to visit the family in groups as a safety measure. An example of an interview, to negotiate entry into the home of a community member, was portrayed in class by the two lecturers before students were exposed to the community. Students were divided into small groups and given scenarios to practice in preparation for their initiation into the community. However, it was not known how students would experience this learning task, given the diversity of socio-economic factors, cultures and health profiles they would encounter.

\section{Research objectives}

The research objectives of the study were:

- To explore and describe the experience of undergraduate nurses of the family health assessment as a learning opportunity.

- To make information available about the lived experiences of undergraduate nurses' experience of the family 
health assessment as a learning opportunity to inform curriculum review.

In view of the objectives the following question was posed to guide the research study: 'how did you experience completing the family health assessment?'

This article will focus on a description of the research methodology used for the study, experiences of participants, discussion of the research results, the conclusion and recommendations made.

\section{Contribution to the field}

The aim of the study was to inform future research and curriculum planning for Community Health Nursing Education in a multifaceted context, focusing on the importance of the family health assessment.

\section{Research method and design}

A qualitative approach and phenomenological design was used to explore the meaning of the lived experiences (Creswell 2003:15) of the undergraduate CHN students as described by them individually. Qualitative research is concerned with everyday human experiences within the natural environment (Wilson 1989:455-456). In-depth individual interviews allowed searching for similarity in meaning of the core experiences of the participants. The participants' responses were explored until a position of saturation was reached, when no new data emerged and the themes identified were coded and integrated (Cormack 2000:159).

\section{Population and sample}

The purposive and convenience sample consisted of thirdyear CHN students from UWC who had been exposed to an FHA. Participants who volunteered to take part were included in the sample as they were accessible (Hek, Judd \& Moule 2003:67-68). This meant that the researcher had to include conscious selection criteria for certain subjects, elements, events or incidents in the study. Inclusion criteria for the study were as follows: voluntary participation, students who had completed an FHA and students willing to share lived experiences of conducting the FHA in a community.

After a short oral presentation, information leaflets and consent forms were handed to all who attended the information session. Fourteen participants who met the inclusion criteria - a convenience sample - volunteered to take part. Only nine participants were interviewed since two withdrew from the study and the remaining three were not interviewed since no new data had emerged during data analysis, in other words, data saturation had been reached.

\section{Data collection}

Data collection was done through in-depth interviews that were audio-recorded and transcribed to gain deeper insight into the experiences of the participants. Interviews are the most frequently used method for the collection of data in qualitative research (Kvale 1996:29-31). For this particular study indepth interviews were conducted to obtain information on and an understanding of relevant issues pertaining to the general aims of this study. The specific research question that guided the phenomenological interviews to explore the lived experiences of the students was as follows: 'How did you experience the FHA?' Additional field notes were taken to capture non-verbal communication of the students. The duration of the interviews varied between 90 and 120 minutes.

Transcriptions of the interviews were done on the same day as the interviews were carried out by the researcher. On completion of the transcriptions they was printed and verified by each of the participants, before any of the information was used in the study. Individually transcribed interviews ranged between four and ten pages in length.

\section{Data analysis}

The data that were collected were categorised into themes according to their shared commonality and according to Tesch's (1990) method (cited in Creswell 2003:192), which includes eight steps for data analysis:

1. Read through all transcribed interviews to search out a sense of the whole with attentiveness, to reflect on the overall meaning and general impression of all the participants.

2. Decide on one interview (the most appealing), keeping in mind its fundamental meaning. Attempt to comprehend the data by asking yourself what it is all about. The substance is not what is important, but the underlying meaning. Write summarising thoughts in the margin.

3. After completing the above mentioned with all the transcripts, compile a list with all the topics identified. Group similar topics together into columns that may be arranged as major topics, unique topics and leftover topics.

4. This compiled list of topics should now be re-checked with the data collected by the researcher. The topics should be abbreviated as codes, and these codes written in the margin next to the appropriate sections of text. This provides an opportunity to see if new categories or themes emerge.

5. Descriptive words for topics must be identified. Topics that relate to each other are clustered together to reduce the total list.

6. Use abbreviations for each category; place the codes in alphabetical order.

7. Related data in each category should be assembled in one area to perform a preliminary analysis.

8. If indicated, the existing data should be recoded.

The researcher followed seven of the eight steps to analyse the data collected. Step six above was excluded, as the researcher did not use abbreviations for any category identified or place the codes in alphabetical order. The interviews were 
manually transcribed and the responses were categorised into themes by reading through the transcriptions and colour-coding similar remarks of the participants on their experiences in the community whilst conducting an FHA.

\section{Results}

Four themes were identified to describe the lived experiences of the undergraduate community health students doing an FHA within family homes. Verbatim quotes were included in the body of the article to succinctly capture the essence of each theme.

\section{Theme 1: Safety challenges whilst in the community}

Some participants related safety challenges that they experienced whilst conducting the FHA within family homes and the community. Seven of the nine participants in the study verbalised that there was some form of threat to their physical safety here are some of the comments:

'I'm familiar with the place, because I live nearby ... we know that in that side is normally dangerous most of times so I didn't take my phone with me, I left the phone at home.' (Participant 2)

'Now the thing is in our area, it might be a very quiet area, there's no gangsterism and things like that but, tik [methamphetamine], you can order tik, you can dial and they can deliver it to your house.' (Participant 5)

'The ... area is very, it's dangerous, it's not safe. I did not feel safe, because most of all ... I'm from Gauteng, from a small town in Gauteng, where everything is just quiet, now all of a sudden you have to be exposed to this kind of ... it's a horrible place to be in. You don't feel safe to even go into a shop and even coming standing outside, waiting for the clinic to open, you just don't feel safe.' (Participant 7)

Two female students worked within a community in which one of them resides. The participant related that she relied on her colleague to guide and negotiate their entry into a family home and the community, but this turned out to be a major challenge. The student who lives within that community indicated that she was afraid to go into the community on foot due to gang-related activities, and to ensure her safety she was being taken by car to and from the health facility by a member of her family. The other student relates:

'We were two students, the one stayed in Community A, but she ... don't even know the place ... I rely on her, because... I'm from Community B, I only work there ... but she was as lost as I were so we asked around in the streets ... but we were very particular for who we ask. We only ask women and maybe small children. And there are gang activity in Community A ... the other student ... don't know that area ... and there were a lot of ... gangs standing there and they smoke ... they was like teasing us, but we just ignored them. Yes, she was scared and she is very nervous, she can get ... scared very easily, because ... she's used to ... driving with a car to the facility or one of her family members they took her there, but she don't walk from the house to the clinic, like alone.' (Participant 4)

A male participant shared how he and some female participants managed a situation with a family member who had recently completed a period of imprisonment after being convicted for rape and murder:

'... we found that on every second corner of the street there was like groups of young men ... some of them were old some of them young, but you know ... the gangster looking guys. They look like gangsters, we found them on the streets and ... giving comments to, to people who's passing by so... yes we were accompanied but, I think ... not with adequate safety methods.'

'There were also a, a few safety issues with this family because it was myself and two other ladies ... that accompanied me to the family. One of our family members which is a male would talk to me about his social problems and issues and how he deals with it. So he obviously mentioned a few gangster-related type of ... things like gambling and he's been in jail for killing and raping and things like that. So we had to sort of find better coping mechanism and sort of try and cut our visits short with the family so that we can just get done so we can try to prevent situations where we will only find him at home.' (Participant 9)

One of the participants in the study related how the safety of the students was assured by the facility that provided them with transportation.

'The clinic didn't want us to walk to my family's address and they gave us a brief explanation why not. They said that gangsterism, robbery is very prominent in that area and they would feel safer if they will drop us and come fetch us. With our first visit we were dropped off at the family when we entered the area in which they live you could feel ... that tense unsafe feeling was in the air. The clinic staff also warned us not to take any valuables, cell phones, money, and jewellery with because we could be a target.' (Participant 1)

Another participant reported receiving no assistance:

'... my worst experience was the fact that we as students was going alone there and the clinic sister or the manager there wasn't even prepared to help us maybe because there is a lot of transport because there are a lot of transport. They didn't even want to take us there, so they just leave us on our own. That was the worst experience that they were not, they are not into students.' (Participant 4)

As can be seen from the above, not all participants received support and guidance at the facilities during their clinical placement period. At certain facilities students ventured into the communities unescorted. Their safety requirements did not appear to be the main concern of the facility personnel. Since they knew their community and the physical location of clients, the expectation was that facility staff would guide the students in their selection of families to be interviewed within their homes, ensuring that the students did not enter into a compromising situation.

One participant indicated that she took safety precautions as she walked to the home of the family, since she was familiar with the environment. She was aware of which measures to take to ensure her safety, for example, not taking anything valuable, such as her mobile phone, with her. Having a visible article of value with her might have led to mugging or even bodily harm should she have refused to hand it over:

'I'm familiar with the place ... because I live nearby... we know that in that side is normally dangerous most of the times so I 
didn't take my phone with me, I left the phone at home, I only have the exam pad and a pen to write.' (Participant 2)

The students' statements reflected concern for their physical safety.

\section{Theme 2: Challenges of family selection}

Students go into community health clinics needing to achieve clinical learning outcomes, one being to complete an FHA within the community. Students who were assisted by the facility personnel in the selection of a family to interview indicated relief:

'I consulted some of the staff members to ... find a family that I could work with. There was a bit of, not difficulty but a disagreement in which family I should choose because there was two families that they identified.' (Participant 1)

'... we get hold of him through the ... clinic sister, the TB sister and ... she ask ... his permission ... and she explained everything to him and so he invite us to ... the home ...' (Participant 4)

'My best, my best experience was when our facilitator, the sister in charge of the family study she told us that ok she will take us there ... She even offered to introduce us, to introduce us to the family so that they may not feel that we're there to intimidate them ...' (Participant 7)

In another instance, a community worker who is engaged with tuberculosis treatment ( DOTS) was approached to help identify a family for the assignment.

'So, we got an excellent opportunity with the DOTS supporters to go and assess the community first. I was quite concerned about safety because I don't know the area very well, but going into the darker sides of the area 'cause we had to sort of reach out to patients that didn't get medication at the time or we had to go and look for patients, to bring them back to the clinic so that they can get the medication and follow their treatment. We had to go from house to house ... to find a perfect family and it was quite difficult.' (Participant 9)

Participants did not receive the same kind of assistance, some ventured into the communities unescorted in search of a family, whilst three interviewed families who were known to them and stated that they expected this to make it easier to complete the family study.

'So in my mind I just ... just picked that family I don't know why, but I thought this family can make my family study like good, but I didn't have the guts to go inside.' (Participant 2)

'... we kind of disagreed ... I didn't think they were the right family, she thought (fellow student) that it was the right one. Finally I agreed because we had no other choice.' (Participant 7)

'... the problem is ... my colleague, she is the one who knows the family and then the family didn't accept ... to do our ... assessment.' (Participant 8)

However, the latter found that it was not easy to get participation from a family just because they knew the people personally, and also the family was not prepared to divulge personal information to someone known to them.

\section{Theme 3: Socio-cultural challenges}

Participants were able to identify different socio-cultural and family practices and noted that they respected these.
During the FHA some of the participants were able to experience a culture different to their own, this paved the way to understand and show respect for diversity. Language is another aspect of diversity in South Africa. Participants reported not always understanding clients' home language (there being 11 official languages in South Africa). Personal privacy was recognised as important to the family:

'A lot of times in the Coloured [mixed race] community they don't want people to know what's really happening in their homes. It's more of a cultural thing and they don't want people to know, even though you [are a] nurse they keep things from you unless they really grow to trust you.' (Participant 3)

Participants identified socio-cultural issues where families were not comfortable to tell the student about personal challenges faced in their homes:

'Firstly ... my experience in the family study's that ... these ... in the families ... more especially ... where we did our family study in Khayelitsha and it's a ... a 'Black' area. And then ... the father's ... they still believe that they are the heads of the families and then they don't allow anything 'cause we went there firstly and there was only the mother in the house. And the mother did not give us any information.' (Participant 8)

Doutrich and Storey (2004:305) narrate the experiences of a nurse who had a long-term client with whom she built a trusting relationship. Through this relationship she was able to receive an articulated description of the cultural beliefs, traditions and values of this family upon invitation into their home.

It is evident that a trusting relationship has to be established to complete a comprehensive health assessment. Devising enough time to establish such a relationship may prove to be challenging for students, who go into the community only once per week over a seven-week period.

'... most of the families or the houses that we ... visited were 'Black' people and it was quite difficult for us to get a family because it's [either] ... the families don't understand the ... my language or I don't understand their language.' (Participant 9)

One participant indicated that he was challenged by a language barrier whilst trying to locate a family to complete the FHA task.

\section{Theme 4: Academic challenges}

Some of the participants indicated that they were 'bombarded' with work at the health facility, and that this delayed their progress with the FHA. The participants indicated that the workload within the facility initially led to insufficient outreach opportunities to families, which created the anxiety that they were not going to meet the expected outcomes for their clinical placement. After some time they were able to leave the facility to locate a family in order to complete their FHA task:

'Ok ... at first finding the family in the community ... just the thought of it was, brought some difficulties into my planning because at the clinic we weren't exposed at first to ... to sort of get to know the families well. ...we were bombard with, with a lot of work and I thought that we won't have enough time to go into the community.' (Participant 9) 
Participants indicated that they did not initially understand the expected outcomes of the assignment and how the family interviews were to be conducted following are some of the concerns:

'The family study, from the beginning was very confusing when we first received the information and the guidelines to do what we were suppose to do. It was very confusing, but the lecturers helped out a lot by explaining any questions we had.' (Participant 3)

'... it is difficult for a student to go to a family only as a student because, most families will expect you to give advise regarding their health problems that you see in that family ...' (Participant 6)

'I thought you were, it was compulsory for us to interview the family in groups. I never knew that we are ... allowed to choose your own family ... if I understood that part maybe I would've got, had another family that...' (Participant 7)

One participant verbalised how unhappy she was with the mark obtained after working so hard completing the FHA.

'... But I only get forty per cent. Then I was surprised. So to me, - ah - After that I said what's the use I've put in - ah - like a lot of effort in this assignment or maybe I didn't listen like to the instructions ... and I was honest. I went to the family but, I only got forty per cent although there are people who just made their own families, but...' (Participant 2)

The assessment tool was discussed with the participant and she discovered that she had missed out on crucial information in the assignment.

'... I've put in - ah - like a lot of effort in this assignment or maybe I didn't listen like to the instructions ...' (Participant 2)

\section{Ethical considerations}

Ethical approval to conduct the study was obtained from Senate Higher Degrees, the Senate Research Ethics Committee, Registrar of the University and Director of the School of Nursing of the UWC. All participants were informed verbally and in writing of the purpose of the study, and written consent was obtained from them. No monetary incentives were offered to potential research participants. Participants were informed that they could withdraw from the study at any stage and that their responses would have no negative influence on their studies since they had completed the $\mathrm{CHN}$ module. Confidentiality was ensured as the participants were given a numerical code at the start of the in-depth interview, which was used when reference was made to them during the interview and that subsequently appeared on the transcriptions to protect their identity. The names of participants only appeared on the consent forms that were kept in a secure place.

\section{Trustworthiness}

Heidegger (1889-1976) in Morse (1994:140-147) and Gooddard and Melville (2001:116-117) state that the credibility and affirmation of phenomenological research can be described as confidence in the concept of the truth of the data collected. The researcher made an explicit attempt to capture the experiences of the participants in the process through which themes were identified. A second person, the research supervisor, also identified themes in order to establish consensus in the thematic analysis of the research findings. Themes identified during data analysis were supported by direct quotes from participants.

Guba and Lincoln (1981:186) state that to ensure credibility for qualitative findings, the researcher should leave an 'audit trail' for review of data collected. Procedures used to conduct the study and arrive at findings have been made explicit. Credibility was established by carrying out the study in a context that was pertinent to the participants, by purposive selection of participants who had the relevant experience, and careful generation of themes that were agreed upon by two people (Graneheim \& Lundman 2004:105-112).

Trustworthiness was enhanced as transcripts were handed back to the participants to check the information captured and the researchers' understanding of the data through providing critical commentary on the findings. This was done to enhance the accuracy and richness of the final report (Guba \& Lincoln 1981:186).

Dependability refers to the ability to retain data without changes that may occur over time. In this case data were collected and analysed directly after completion of the individual interviews, and an audit trail was established. The quotes from participants further enhanced the understanding of transferability (Graneheim \& Lundman 2004:105-112). These aspects could also contribute to conformability, that is, the notion that data and findings were congruent and that there were no undue extraneous influences.

\section{Discussion}

\section{Theme 1: Safety challenges whilst in the community}

Workplace danger and violence becomes a reality when working in communities, and this has an indirect effect on the quality of care rendered to those in need. Expensive jewellery should not be worn, since it may attract unnecessary attention, and wearing high heels may hinder walking fast or running should there be a safety threat. The personal safety of health care workers may be a concern, whilst within communities; awareness about community violence and relevant training reduces the risk to health care workers (Anderson 2008:534540). Fazzone, Barloon, McConnell and Chitty (2000:43-52) commented that further research was needed to explore the ethics of placing students in communities with a known profile of violence, and suggested that health care workers keep their visits short, knowing that this may have an impact on the quality of the care being rendered.

South Africa has a high level of crime: for example, the extent of robberies with aggravating circumstances for 2008-2009 was at 249.3 per 100000 members of the population, and sexual assault for 2008-2009 was at 146.9 per 100000 (South African Police Services 2008/2009). A comparison of the murder rates in South Africa in 2008 (Flanagan 2009) stood 
at 37 per 100 000, compared to those in Venezuela (48 per 100 000) and the United Kingdom (2 per 100 000) (McDermott 2008) that year, indicates the risk to participants within South African communities whilst conducting FHAs.

In a survey by Fry, Riordan, Turner and Mills (2002:112120) of aggressive incidents experienced by community mental health staff, participants working in a mental health institution were found to be at increased risk of experiencing aggression and numerous challenges to their safety in the various communities in which they were placed.

\section{Theme 2: Challenges of family selection}

Participants went to great lengths to ensure that they located a suitable family to meet the guidelines necessary for completion of their assignment. An essential part of the development of the community health nurse is to recognise the complexity of the skills required to gain entry into the family unit (Drevdahl, Dorcy \& Grevstad 2001:234-239). This appears to be an under-researched aspect, since little literature could be found on it.

\section{Theme 3: Socio-cultural challenges}

Doutrich and Storey (2004:298-307) explain that cultural competence entails becoming familiar with the detail of beliefs, traditions and values in a family. In a study on the clinical experience of undergraduate students in rural and remote area in Australia, a participant shared how difficult it was to establish rapport with the Central Australian Aboriginal people, until the participant came to understand the multiple problems and diverse cultural challenges that this community was facing (Neill \& Taylor 2002:239-243). This is applicable to South African settings as well. The diversity of families and the multiplicity of their problems may impact on stress levels experienced by the visiting nurse within the community setting (Clark 2008:590). Whilst completing the FHA, some students experienced cultures and languages different to their own. This experience paved the way to understand and show respect for diversity.

Clinical experiences in the community setting provide participants with an opportunity not only to reflect on their own personal values and beliefs regarding race, class and gender, but also to make use of empowerment approaches to gain understanding of the health of communities. This includes being able to identify the influence of the socioenvironmental and cultural factors that have an effect on the health of communities (Drevdahl, Dorcy \& Grevstad 2001:234-239).

International or transcultural learning experiences provide an opportunity for nursing participants to practice their acquired skills in a socio-cultural system different from their own. This may assist the student to gain an increased global perspective that will enhance socio-cultural competency. A study of the experiences of graduates in Nicaragua reported how their knowledge, personal growth and interpersonal connections were influenced upon being transculturally exposed (Kollar \& Ailinger 2002:28-31). By moving beyond personal borders, participants may develop personal bonds with families that could enhance care.

\section{Theme 4: Academic challenges}

Contextual factors may have an impact on the learning task at hand. During clinical placement, students are moved from a sheltered and supportive environment with the focus on learning, into a workplace where they experience continued pressure (Mannix, Faga, Beale \& Jackson 2006:3-11). This transition appears to need further research, particularly in a resource-constrained health care environment (Naudé \& Setswe 2000:12).

\section{Limitations to the study}

The themes that were identified were enhanced and supported by references from pertinent literature in the form of a literature control. The EBSCOhost, Scopus, ProQuest and Scholar Google data bases were accessed through the UWC library system and librarians with expertise were consulted in literature searches; however, published literature pertinent to the specific challenges identified was not readily available. Fry et al. (2000:112-120) also identified a dearth of literature regarding their study on the safety for staff in mental health care facilities.

\section{Recommendations Safety challenges whilst in the community}

Participants expressed concerns about their safety whilst in the community to complete the FHA task. It is recommended that under no circumstances should students be allowed to leave a health facility unescorted to venture into a community where violence is prevalent.

An escort could be arranged to accompany the students into the community, where necessary (e.g. directly observed treatment short course [DOTS] worker, who is a community member). Should a DOTS worker or other staff member not be available, then the placement coordinator should escort the students. It should remain the responsibility of the learning institution to ensure that the students are not placed at a health facility where it is known that their safety will be compromised, nor should they be expected to be exposed to uncertain community conditions.

Before being exposed to the community, students should receive in-depth training in safety measures. Specific training should be given on how to respond to an unsafe situation during the visit, for example, a visible gun or any sort of weapon; offensive verbal or body language of a family or community member; and domestic arguments (Anderson 2008:538).

They should be trained in self-defence strategies; how to stay alert and aware of their surroundings at all times; when 
to leave an unsafe home or community immediately; when and how to immediately call the police and their placement coordinator; how to trust their instincts and avoid situations that feel dangerous; and how to carry a pepper spray or a similar device to discourage an attack on personal safety (Anderson 2008:538).

Students should be dressed comfortably and professionally, preferably in the prescribed uniform, with their identity disc clearly visible and comfortable walking shoes.

It is also recommended that the clinical facility adopts a movement diary, since the facility manager and staff need to be aware of the students' whereabouts at all times. This should be initiated at all health facilities where students are placed and not only in communities where there have been incidents of violent or gang-related activity.

Team-building initiatives between the staff at the health facilities and the university staff may reinforce and strengthen lines of communication to address common safety problems.

\section{Challenges of family selection}

The placement coordinator in liaison with the relevant lecturer should be available to provide guidance to students where needed through a continued mentoring programme. Again, where needed, the simulated learning situation should be recreated to give the student an opportunity to negotiate entry into the home of a family without fear of outright rejection.

\section{Socio-cultural challenges}

Participants in the study displayed sensitivity to sociocultural aspects, but there is a need to enhance this. Participants may be helped to develop skills to manage sociocultural differences, for example to become familiar with the detail of cultural beliefs, traditions and values in a family within our diverse South African communities prior to and during clinical placement, such as through clinical tutorials.

\section{Academic challenges}

Participants expressed difficulty with the workload versus the learning task whilst in the clinic setting, which led to academic challenges. A distinction between learning and working tasks needs to be agreed to by all role players concerned with student learning when negotiating student placements. The undergraduate nursing clinical programme, through which students are placed at health care facilities, is important in the preparation for professional practice. Clear and structured guidelines should be provided to the health facility manager upon arrival of the student at the facility, stipulating the expected clinical learning outcomes for the student.

\section{Conclusion}

The main focus of this study was to explore the lived experiences of undergraduate $\mathrm{CHN}$ students at UWC who conducted an FHA learning task at families' homes within communities. This qualitative phenomenological study has exposed a broad perspective of the difficulties that the participants encountered when negotiating entry into the homes of families, even though this process was simulated in the class setting. However, to ensure clinical and academic growth the selection of an appropriate family should remain the primary responsibility of the student, so that they will be able to identify a family at risk.

Community health professionals, lecturers, facility staff and students can use the results of this study to ensure the effective completion of FHAs in communities without compromising the safety of the students.

\section{Acknowledgements}

This research was undertaken as part of the requirements for the degree of a Master's in Nursing Education.

\section{Competing interest}

The authors declare that they have no financial or nonfinancial competing interest or personal relationship(s), which may have influenced them inappropriately in writing this article.

\section{Author contribution}

J.W. (University of the Western Cape) conducted the research, using the methodology designed by J.W. and E.K. (University of the Western Cape). E.K. provided conceptual guidance whilst most literature was sourced by J.W. in collaboration with E.K.

\section{References}

Allender, J.A., Rector, C. \& Warner, K.D., 2010, 'Community Health Nursing. Promoting and Protecting the Public's Health, 7th edn., Wolters Kluwer Health/Lippincott \& Williams, Philadelphia.

Anderson, N.R., 2008, 'Safe in', Home Healthcare Nurse 26(9), 534-540, viewed 11 September 2009, from: http://www.homehealthcarenurseonline.com

Clark, M.J., 2008, Community Health Nursing: Advocacy for Population Health. 5th edn., Pearson \& Prentice Hall, New Jersey.

Cormack, D., 2000, The Research Process in Nursing, 4th edn., Blackwell Science, London.

Creswell, J., 2003, Research Design. Qualitative, Quantitative, and Mixed Methods Approaches, 2nd edn., Sage Publications, Thousand Oaks.

Croxon, L. \& Maginnis, C., 2009, 'Evaluation of clinical teaching models for nursing Practice', Nurse Education in Practice 9, 236-342. http://dx.doi.org/10.1016/j. nepr.2008.06.004, PMid:18722161

Doutrich, D. \& Storey, M., 2004, 'Education and Practice. Dynamic Partners for Improving Cultural Competence in Public Health', Family Community Health 27(4), 298-307.

Drevdahl, D., Dorcy, K.S. \& Grevstad, L., 2001, 'Integrating Principles of Communitycentered Practice in a Community Health Nursing Practicum', Nurse Educator 26(5), 234-239. http://dx.doi.org/10.1097/00006223-200109000-00013, PMid:12144342

Fazzone, P.A., Barloon, L.F., McConnell, S.J. \& Chitty, J.A.,, 2000, 'Personal Safety, Violence and Home Health', Public Health Nursing 17(1), 43-52. http://dx.doi. org/10.1046/j.1525-1446.2000.00043.x, PMid:10675052

Flanagan, F., 2009, 'SA murder rate drops', viewed 7 May 2010 from http://www.iol. co.za/index.php?art_id=vn20091204041545681c566421

Fry, A.J., Riordan, D., Turner, M. \& Mills, K.L., 2002, 'Survey of aggressive incidents experienced by community mental health staff', International Journal of Mental Health Nursing 11(2), 112-120. http://dx.doi.org/10.1046/j.14400979.2002.00234.x, PMid:12430192

Gooddard, W. \& Melville, S., 2001, Research Methodology: An Introduction, 2nd edn., Juta, Lansdowne. 
Graneheim, U.H. \& Lundman, B., 2004, 'Qualitative content analysis in nursing research: concepts, procedures and measures to achieve trustworthiness', Nurse
Education Today 24:105-112. http://dx.doi.org/10.1016/j.nedt.2003.10.001, Education Todey 14769454

Guba, E.G. \& Lincoln, Y.S., 1981, Effective Evaluation. Improving the Usefulness of Evaluation Results Through Responsive and Naturalistic Approaches, Jossey-Bass Evaluation Results Thro
Publishers, London.

Harmon Hanson, S.M., Gedaly-Duff, V. \& Rowe Kaakinen, J., 2005, Family Health Care Nursing. Theory, Practice and Research, 3rd edn., F.A. Davis, Philadelphia.

Hattingh, S., Dreyer, M. \& Roos, S., 2006, Aspects of Community Health. South Africa. Oxford University Press Southern Africa, Cape Town.

Hek, G., Judd M., \& Moule, P., 2003, Making sense of Research. An Introduction for Health and Social Care Practitioners, 2nd ed., Sage Publishers, London.

Kvale, S., 1996, Interviews. An Introduction to Qualitative Research Interviewing, Sage Publishers, Thousand Oaks.

Kollar, S. \& Ailinger, R., 2002, 'International Clinical Experience: Long-term impact on Students', Nurse Educator 27(1), 28-31. http://dx.doi.org/10.1097/00006223200201000-00016, PMid:11840069

Mannix, J., Faga, P., Beale, B. \& Jackson, D., 2006, 'Towards sustainable models for clinical education in nursing: an on-going conversation', Nurse Education in Practice 6(1),3-11. http://dx.doi.org/10.1016/j.nepr.2005.05.004, PMid:19040850

Maurer, F.A. \& Smith, C.M., 2009, Community/Public Health Nursing Practice. Health for families and populations. 4th edn., Saunders/Elsevier, St Louis, Mo.
McDermott, J., 2008, 'Venezuela's murder rates surpass Colombia's under Hugo Chavez', viewed 7 May 2010, from http://www.telegraph.co.uk/.../venezuela/.../ Venezuelas-murder-rates-surpass-Colombias-under-Hugo-Chavez.html

Morse, J., 1994, Critical issues in qualitative research method, Sage Publishers, Thousand Oaks.

Naudé, M. \& Setswe, G., 2000, Basic Community Health Nursing, Heinemann Publishers, Sandown.

Neill, J. \& Taylor, K., 2002, 'Undergraduate Nursing Students' Clinical Experiences in Rural and Remote Areas: Recruitment Implications', Australian Journal of Rural Health 10,239-243. http://dx.doi.org/10.1046/j.1440-1584.2002.00482.x, PMid:12230431

Sebastian, J.G. \& Stanhope, M., 1999, Case Studies in Community Health Nursing Practice. A Problem-Based Learning Approach, Mosby, Missouri.

South Africa, 2005,Nursing Act: Act No. 33 of 2005, Government Gazette 491, 28883, Government Printer, Pretoria.

South African Nursing Council, 1985, Regulation 425 of 22 February 1985. Regulations relating to the approval of and the minimum requirements for the education and training of a Nurse (General, Psychiatric and Community) and Midwife leading to registration, Government Printer, Pretoria.

South African Police Services, 2008/9, Crime Statistics, 2008/2009, viewed 9 October 2009, from http://www.saps.gov.za/saps_profile/strategic_framework/annual report2008_2009/2_crime_situation_sa

Walker, L.O. \& Avant, K.C., 2005, Strategies for Theory Construction in Nursing, 4th edn., Pearson Education, New Jersey.

Wilson, H.S., 1989, Research in Nursing, 2nd edn., Addison-Wesley Publishing, California. 